\title{
Suckling Time of Oxytocin and Ethyl Acetate Fraction of Hibiscus Sabdariffa $l$. to Aid Gland Evacuation
}

\author{
${ }^{1}$ Bako, I. Gaya, ${ }^{2}$ Mabrouk, M. Abdelaziz., ${ }^{3}$ Abubakar, M. Suleiman, \\ ${ }^{1}$ Mohammed A. \\ ${ }^{I}$ Department of Human Physiology, Faculty of Medicine, Ahmadu Bello University Zaria, Nigeria \\ ${ }^{2}$ Department of Medical Physiology, Faculty of Medicine, Al- Azhar University Cairo, Egypt \\ ${ }^{3}$ Department of Pharmacognosy and drug Development, Faculty of Pharmaceutical Sciences, Ahmadu Bello \\ University Zaria, Nigeria
}

\begin{abstract}
Suckling time to aid gland evacuation of oxytocin and ethyl acetate fraction of Hibiscus sabdariffa l. seed was evaluated in lactating rats. The 12 lactating rats were allocated at random to 2 treatment groups to determine the rate of suckling with the aid of oxytocin and ethyl acetate fraction $\mathrm{H}$ i b is c u S $s$ a $b d$ a $r$ iff $a$ l. The 2 treatments were 6 different suckling times of 3-96 minutes arranged in geometric progression. Each of the suckling time in the 2 treatments was applied with the aid of subcutaneous injection of 0.1 iu oxytocin immediately prior to suckling and $50 \mathrm{mg} / \mathrm{kg}$ ethyl acetate fraction Hibiscus sabdariffa l. respectively. Treatments were carried out on days 3, 6, 9, 12, 15 and 18 of lactation. The amount of milk sucked by the litters in the various suckling times showed that, the oxytocin enabled the pups to remove the milk more rapidly than the ethyl acetate fraction of Hibiscus sabdariffa l. Oxytocin a lactogenic hormone causes myoepithelial contraction for milk letdown through ejection reflex during lactation, while ethyl acetate fraction of Hibiscus sabdariffa l. has a relaxing effect.
\end{abstract}

Key words: Hibiscus sabdariffa l.; lactation; ethyl acetate; milk; dam; pups.

\section{Introduction.}

The accurate estimate of milk yield in the rat is an important component in lactation research. The measurement of milk production rates in rats is difficult, $[15,24]$ however a more feasible direct method is to use the pups to remove the milk from the dam and to determine the amount of milk sucked by the litter [1]. Milk yield estimations for rats by means of pup weight and weight gains have been used in several studies $[15,22,10$, $11,20]$. The most commonly employed method has been the test-weighing procedure which consists of weighing infant pre and post suckling difference is the amount of milk ingested. The weight gain of pups is commonly used as an index of milk secretion, with direct estimates of milk yield by measuring litter weight gain during suckling intervals that follow some period of separation of dams and litters, corrected for insensible weight loss of the pups $[14,22]$. The cycles of separation periods and reunion of dams and pups had to be long enough to minimize handling of pups and dams. Nevertheless, non-suckling intervals had to be short enough to avoid adverse effects that separation might have on dams and pups $[9,22,20]$. Hibiscus sabdariffa l. is a lactogenic herb $[7,19]$ belonging to the malvaceae family and it is grown in Central and West Africa, South East Asia, and elsewhere in parts of World. The mechanism through which Hibiscus sabdariffa l. exerts its action may be through dopamine receptors as dopamine antagonist, because dopamine blocked the extract effect. However, oxytocin is a lactogenic hormone that causes milk letdown through ejection reflex during lactation. The study is designed to assess the suckling time of ethyl acetate fraction of Hibiscus sabdariffa l. in lactating albino rats.

\subsection{Experiment site.}

\section{Materials and methods.}

The study was carried out in Department of Human Physiology, Faculty of Medicine, Ahmadu Bello University, Zaria. Zaria is located between latitudes $11^{\circ}$ and $3^{\prime} \mathrm{N}$, and between $7^{\circ}$ and $42^{\prime} \mathrm{E}$, at an altitude of $670 \mathrm{~m}$ above the sea level and $664 \mathrm{Km}$ away from the sea, in the Northern Guinea Savanna zone. The average rainfall in Zaria is approximately $1000 \mathrm{~mm}$, mainly during the month of March to October. The maximum ambient temperature range in Zaria is $27-35^{\circ} \mathrm{C}$ with a dry and wet season [13].

\subsection{Chemicals and drugs.}

Ethyl acetate puriss Reg No 27227 Sigma-Aldrich $^{\circledR}$, Oxytocin (NAFDAC Reg. no. A4-2960) and Chloroform Poole, BH15 1TD England were used for the experiment. All the chemicals and drugs used are of analytical grade. 


\subsection{Collection of Hibiscus sabdariffa $l$. seed.}

The samples of Hibiscus sabdariffa $l$. seed were collected in Gaya Hong Local Government in Adamawa state of Nigeria in November 2012. The plant was identified in the Department of Biological Sciences, Ahmadu Bello University, Zaria by a taxonomist authenticated with a voucher number 1056 and deposited in the Herbarium section of the Department of Biological Sciences, Ahmadu Bello University Zaria, Nigeria.

\subsection{Preparation of the plant extract.}

Extraction and Fractionation was conducted in Department of Pharmacognosy and drug development, Ahmadu Bello University Zaria. Extraction was done using maceration method while the crude aqueous extracts were fractionated by using Ethyl acetate reagents.

\subsection{Animal management}

Twelve female albino rats weighing 180-240g were obtained from the Animal house of Department of Human Physiology Ahmadu Bello University, Zaria. The animals were housed and mated with the male rats in a stainless steel metal cage under standard laboratory condition with $12 \mathrm{~h}$ dark/light cycle. They were fed with commercial feeds and tap water ad libitum. Following birth, the litters' weights were recorded and culled to 6 litters per dam.

\subsection{Acute toxicity studies.}

\section{Experimental Protocol.}

The lethal dose $\left(\mathrm{LD}_{50}\right)$ of the plant fraction was determined by the method of Lorke [12] using 13 rats. In the first phase rats were divided into 3 groups of 3 rats each and treated with the ethyl acetate fraction of Hibiscus sabdariffa $\quad$. seed at doses of 10,100 and $1000 \mathrm{mg} / \mathrm{kg}$ body weight intraperitoneal. They were observed for $24 \mathrm{~h}$ for signs of toxicity. In the second phase 4 rats were divided into 4 groups of 1 rat each and also treated with ethyl acetate fraction of $\mathrm{Hi}$ b is c us sab d a riff a l. seed at doses of 1000, 1600, 2900 and $5000 \mathrm{mg} / \mathrm{kg}$ bodyweight (i. p). The median lethal dose $\left(\mathrm{LD}_{50}\right)$ was calculated using the second phase.

\subsection{Experimental design.}

12 lactating rats were allocated at random to 2 treatment groups to determine the rate of suckling with the aid of oxytocin and ethyl acetate fraction of Hibiscus s a b d a riffa l. The 2 treatments were 6 different suckling times of 3-96 min arranged in geometric progression. Each suckling time was applied with the aid of subcutaneous injection of 0.1 iu oxytocin immediately prior to suckling and $50 \mathrm{mg} / \mathrm{kg}$ of ethyl acetate fraction Hibiscus sabdariffa $l$. respectively. The 2 treatments groups were arranged that each rat received 6 treatments, during all the suckling times, 6 with oxytocin and 6 with Hibiscus sabdariffa l. respectively. Treatments were carried out on days 3, 6, 9, 12, 15 and 18 of lactation. The pups were with the dams throughout the experiment except during a secretion interval of $12 \mathrm{~h}$ prior to treatment suckling on the 6 test days.

\subsection{Data analysis}

All data are expressed as mean \pm standard of error mean (Mean \pm S.E.M.). The data obtained were analyzed using t- test student-Newman Keul's test [5], SPSS package version 20.0 and post hoc test for multiple comparisons. The $(\mathrm{P}<0.05)$ was accepted as significant.

\subsection{Toxicity studies}

\section{Results.}

The plant seed fraction is characterized by a very low degree of toxicity. The acute toxicity $\mathrm{LD}_{50}$ of ethyl acetate fraction of Hibiscus sabdariffa l. seed in albino rats was found to be above $5000 \mathrm{mg} / \mathrm{kg}$ according to the method of Lorke [12].

\subsection{Suckling Time of Oxytocin and Ethyl Acetate Fraction of Hibiscus Sabdariffa $l$. to aid gland evacuation.}

This experiment was carried out to compare the rate of suckling with the aid of oxytocin and ethyl acetate fraction of Hibiscus sabdariffa $l$. In figure 4.1 the amount of milk sucked by the litters in the various suckling times showed that, the oxytocin enabled the pups to remove the milk more rapidly than the ethyl acetate fraction of Hibiscus sabdariffa $l$. The amount milk sucked by 6 groups of pups during suckling times of 3-96 minutes from dams which received 0.1 i $\mu$ of oxytocin is significantly $(\mathrm{P}<0.05)$ higher than the ethyl Acetate 
fraction of Hibiscus sabdariffa l. Although oxytocin did not affect the total amount milk removed during suckling peroids 48-96 minutes since the secretion peroid is 1 hour.

\section{Figures.}

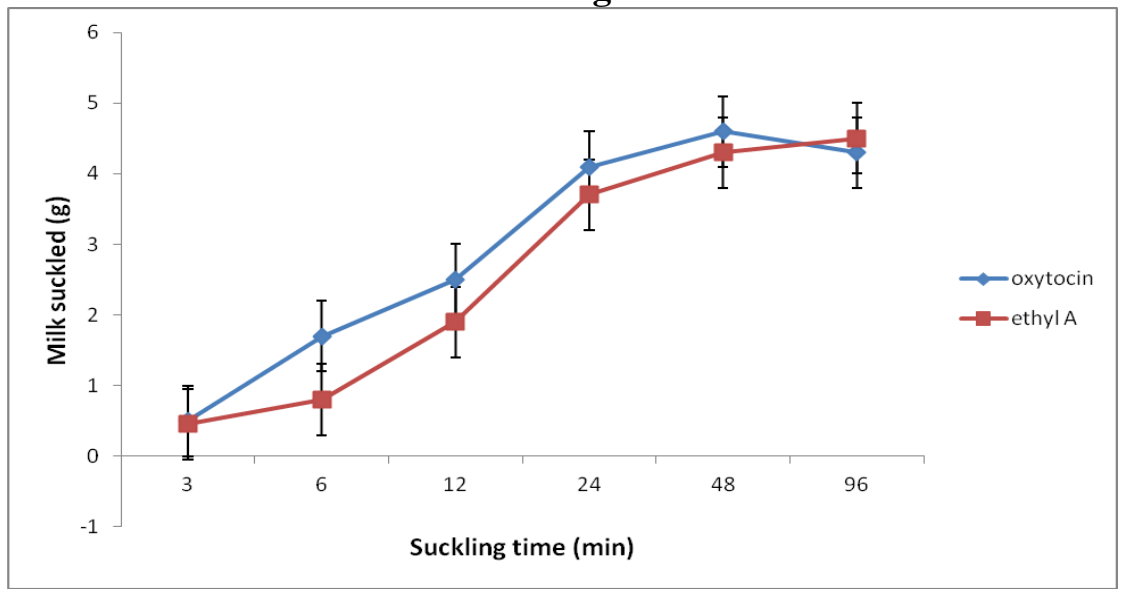

Figure 4.1: Suckling Time of Oxytocin and Ethyl Acetate Fraction of Hibiscus Sabdariffa l. to aid gland evacuation.

\section{Discussion.}

The result of suckling time to aid gland evacuation of oxytocin and ethyl acetate fraction of Hibiscus sabdariffa $l$. seed showed that the amount of milk sucked by the litters in the various suckling times in oxytocin is significantly $(\mathrm{P}<0.05)$ higher than that of ethyl acetate fraction of Hibiscus sabdariffa $l$. The rate of suckling with the aid of oxytocin enabled the pups to remove the milk more rapidly than the ethyl acetate fraction of Hibiscus sabdariffa l. This shows that the activity of ethyl Acetate fraction of Hibiscus sabdariffa l. on the myoepithelial cells is likely relaxation, not contraction as the case of oxytocin. Milk is contnuously secreted into the alveoli of the breast, however to get the milk from the alveoli into the ducts it needs to be ejected. Ejection is a neuronal and hormonal reflex involving oxytocin [23, 21]. Hibiscus sabdariffa $l$. has lactogenic activity because it increases the prolactin secretion [19] with the mechanism through which Hibiscus sabdariffa l. exerts its action may be through dopamine receptors as dopamine antagonist, because dopamine blocked the extract effect. Hibiscus sabdariffa $l$. has been reported to be antiseptic, aphrodisiac, astringent, cholagogue, demulcent, digestive, diuretic, emollient, purgative, refrigerant, sedative, stomachic lactogenic and tonic $[16,6,18,19,8]$. Its antihypertensive action makes it to have a relaxing activity on the smooth muscles [17, 2, 3, 4]. Oxytocin a lactogenic hormone causes myoepithelial contraction for milk letdown through ejection reflex during lactation, while ethyl acetate fraction of Hibiscus sabdariffa l. has a relaxing effect.

\section{Acknowledgement}

The authors are grateful to the following; Mohammad Nura of the Department of Human physiology Ahmadu Bello University, Zaria for the role he played in the laboratory during this research. We also acknowledge mcArthur foundation Ahmadu Bello University, Zaria and University Board of Research of Ahmadu Bello University, Zaria for supporting this research work.

\section{References}

[1]. Ann, H. and J.L. Linzell, 2003. A simple technique for measuring the rate of milk secretion in the rat. Comparative Biochemistry and physiology part A:Physiology. 43(2):259-70.

[2]. Bako, I.G., Mabrouk, M.A. and Abubakar, A. (2009a). Antioxidant effects of ethanolic seed extract of Hibiscus sabdariffa linn (malvaceae) alleviate the toxicity induced by chronic administration of sodium nitrate on some haematological parameters in wistar rats. Advance Journal of food Science and Technology, ISSN: 2042-4876, 1(1):39-42.

[3]. Bako, I.G., Mabrouk, M.A., Maje, I.M., Buraimoh, A.A. and Abubakar, M.S. (2010). Hypotensive effects of aqueous seed extract of Hibiscus sabdariffa linn (Malvaceae) on normotensive cat. International Journal of Animal and Veterinary Science, ISSN: 20412908, 2(1):5-8

[4]. Bako, I.G., Mohammad, S.T., Dawud, F.A., Mohammad, I.M. and Liman, A.A. (2009b). Hypotensive effects of ethanolic seed extract of Hibiscus sabdariffa linn (Malvaceae) on normotensive cats. International Journal of Pure and Applied Science, ISSN 1597-6291, 3(3):22-28.

[5]. Betty, R.K. and A.C. Jonathan, 2003. Essential medical statistics. Second edition. Blackwell science USA. 15-409.

[6]. Chen, C.C., J.D., Hsu, H.C., Wang, M.Y., Yang, E.S., Kao, Y.O., Ho, and C.J. Wang, (2003). Hibiscus sabdariffa extract inhibit the development of atherosclerosis in cholesterol-fed rabbits. J. Agric. Food chem. 51(18): 5472-5477.

[7]. Dalziel, T.M. 1973. The useful plants of west tropical Africa. Third edition: Watmought Ltd idle Bradford and London. 526-530.

[8]. Gaya, I.B., Mohammad, O.M.A., Suleiman, A.M., Maje, M.I. and Adekunle, A.B. (2009). Toxicological and lactogenic studies on the seeds of Hibiscus sabdariffa linn (malvaceae) extract on serum prolactin levels of albino wistar rats, Internet journal of Endocrinology. ISSN:1540-2592:5(2). 
[9]. Hanwell, A. and Linzell, J.L. (1972). A simple technique for measuring the rate of milk secretion in the rat. Comprehensive Biochemical physiology [A]. 43:259-70.

[10]. Kamani, H.T., E.H., Karunanayake, and M.P.D. Mahindartna, 1987. Evaluation of galactoguic activity of Asparagus falcatus. Ceylon Journal of Medical Sciences 30 63-67.

[11]. Kim, S.H., Y.S., Moon, W.L., Keller and C.S. Park, 1998. Compensatory nutrition-directed mammary cell proliferation and lactation in rats. British Journal of Nutrition 79 177-183.

[12]. Lorke, D. 1983. A new approach to practical acute toxicity testing. Archives of Toxicolog, 54: 275-287.

[13]. Marthins, M.I. 2006. Zaria and its region. Department of Geography Ahmadu Bello University, Zaria, pp-41.

[14]. Morag, M. (1970). Estimation of milk in the rat. Laboratory animal. 4:259-72.

[15]. Morag, M., F., Popliker, and R. Yagil, (1975). Effect of litter size on milk yield in the rat. Laboratory Animals 9 $43-47$.

[16]. Morton, J.F. (1987). Roselle. In: fruits of warm climate, (CF Dowling (ed). Media, Inc. Greensboro, NCP. 281-286.

[17]. Odigie, I.P., Ettarh, R.R. and Adigun, S.A. (2003). Chronic administration of aqueous extract of Hibiscus sabdariffa attenuates hypertension and reverses cardiac hypertrophy in 2K-1 hypertensive rats. Journal of Ethnopharmacology, 86: 181-185.

[18]. Olaleye, M.T. (2007). Cytotoxicity and antibacterial activity of methanolic extract of Hibiscus sabdariffa. J Med Plants Research, 1(1): 009-013.

[19]. Okasha, M.A.M., M.S., Abubakar, and I.G. Bako, (2008). Study of the effect aqueous Hibiscus sabdariffa l. seed extract on serum prolactin level in lactating albino rats. European Journal of Scientific Research, ISSN 1450-216X 22(4) pp.575-583

[20]. Ouedraogo, Z.L., D.V., Heide, E.M.V., Beek, H.J.M., Swarts, J.A.M., Mattheij, and L. Sawadogo, (2004). Effect of aqueous Acacia nilotica spp adansonii on milk production and prolactin release in the rat. J. endocrinology, 182:257- 266.

[21]. Riordan, J. and Wambach, K. (2010). Breastfeeding and human lactation (4rd ed.). Sudbury, MA: Jones and Bartlett. Pp-379-380.

[22]. Sampson, D.A. and G.R. Jansen, (1984). Measurement of milk yield in lactating rat from pup weight and weight gain. Journal of Pediatry, Gastroenterology and Nutrition 3613-617.

[23]. Shennan, D.B. and Peaker M. (2000). Transport of milk constituents by the mammary gland. Physiological reviews, 80(3):925-951.

[24]. Taffetani, S., G., Shannon, H., Francis, D., Sharon, U., Yoshiyuki, D., Alvaro, M., Luca, M., Marco, G., Fava, J., Venter, V., Shelley, V., Bradley, P., Ian, H.L., Vien, G., Eugenio, C., Guido, B. Antonio, and G. Alpini, (2007). Prolactin stimulates the proliferation of normal female cholangiocytes by differential regulation $\mathrm{Ca}^{2+}$-dependent PKC isoforms. BMC physiology, doi: 10-1186/1472-6793-76. 